\title{
Factors Associated with Honey Bee Colony Losses: A Mini-Review
}

\author{
Peter Hristov ${ }^{1, *(\mathbb{D}}$, Rositsa Shumkova ${ }^{2}$, Nadezhda Palova ${ }^{3}$ and Boyko Neov ${ }^{1}$ \\ 1 Department of Animal Diversity and Resources, Institute of Biodiversity and Ecosystem Research, \\ Bulgarian Academy of Sciences, 1113 Sofia, Bulgaria; boikoneov@gmail.com \\ 2 Research Centre of Stockbreeding and Agriculture, Agricultural Academy, 4700 Smolyan, Bulgaria; \\ rositsa6z@abv.bg \\ 3 Scientific Center of Agriculture, Agricultural Academy, 8300 Sredets, Bulgaria; nadejda_palova@abv.bg \\ * Correspondence: peter_hristoff@abv.bg; Tel.: +359-2-979-2327
}

Received: 15 September 2020; Accepted: 29 October 2020; Published: 30 October 2020

check for updates

\begin{abstract}
The Western honey bee (Apis mellifera L., Hymenoptera: Apidae) is a species of crucial economic, agricultural and environmental importance. In the last ten years, some regions of the world have suffered from a significant reduction of honey bee colonies. In fact, honey bee losses are not an unusual phenomenon, but in many countries worldwide there has been a notable decrease in honey bee colonies. The cases in the USA, in many European countries, and in the Middle East have received considerable attention, mostly due to the absence of an easily identifiable cause. It has been difficult to determine the main factors leading to colony losses because of honey bees' diverse social behavior. Moreover, in their daily routine, they make contact with many agents of the environment and are exposed to a plethora of human activities and their consequences. Nevertheless, various factors have been considered to be contributing to honey bee losses, and recent investigations have established some of the most important ones, in particular, pests and diseases, bee management, including bee keeping practices and breeding, the change in climatic conditions, agricultural practices, and the use of pesticides. The global picture highlights the ectoparasitic mite Varroa destructor as a major factor in colony loss. Last but not least, microsporidian parasites, mainly Nosema ceranae, also contribute to the problem. Thus, it is obvious that there are many factors affecting honey bee colony losses globally. Increased monitoring and scientific research should throw new light on the factors involved in recent honey bee colony losses. The present review focuses on the main factors which have been found to have an impact on the increase in honey bee colony losses.
\end{abstract}

Keywords: honey bee losses; colony collapse disorder; Varroa destructor; viral diseases; nosematosis; negative pressures

\section{Introduction}

Managed honey bees are the most important pollinators for many crops and wild flowering species. Many countries worldwide, particularly in the Northern hemisphere, rely on the Western honey bee, Apis mellifera, for commercial pollination of certain crops, but over the recent years there has been an increase in losses in managed honey bee colonies in some regions of the world. Colony collapse disorder (CCD) has been reported for the first time in 2006 in the USA [1]. Although some bee losses have also been reported in China and Japan, published data from various investigations have shown that honey bee colony numbers have been stable for the past ten years in these regions [2,3]. The global picture has shown that there are no significant honey bee colony losses reported in Africa, Australia and South America. In the Middle East, the high temperatures and droughts in the summer are the main factor leading to colony losses because many plants, which are important sources for bee forage, 
suffer from heat stress [4]. Another factor aggravating the problem is the lack of comprehensive laws and legislations concerning the importation of bee colonies [5].

Indeed, bee colony losses are not a new phenomenon, and historical records show that extensive losses were not unusual in the past. Whilst recent problems may give the impression that there has been a massive decline, global research on honey bee colonies has shown that numbers actually increased between 1961 and 2007, mostly in Asia (426\%), Africa (130\%), South America (86\%), and Oceania (39\%) [6]. The most significant honey bee colony losses take place during overwintering, as shown by comparisons of colonies going into wintering and surviving the winter. The latter is a symptom of CCD, which has appeared in Europe, causing losses of up to $30 \%$ in some countries [7-9]. It has been difficult to determine a common pattern for the colony losses, but different investigations confirm that it is a phenomenon characteristic of the Western honey bee, while the Asiatic honey bee, present in southern, southeastern, and eastern Asia, appears to be more resistant to various pests and diseases [10].

\section{Role of Pests and Diseases as Drivers Leading to Honey Bee Colony Losses}

To understand the causes underlying the current decrease in honey bee colonies worldwide, it is important to shed light on the key pests and diseases that negatively affect bee health. Honey bees can be affected by various pests and diseases, including mites, different viruses, microsporidia, bacterial infections, and fungi (Ascosphaera apis) (Table 1). Due to the burden of infectious diseases and their agents, honey bee colonies may manifest significant weakness or even death. Only recently have scientists come to understand better the impact of the development and interactions of these pests and diseases.

Table 1. Some honey bee pests and diseases correlated with colony losses.

\begin{tabular}{|c|c|c|}
\hline Type of Pathogen & $\begin{array}{c}\text { Kind of } \\
\text { Relationship }\end{array}$ & References \\
\hline Varroa destructor & Ectoparasitic mite & {$[11,12]$} \\
\hline Acarapis woodi & Tracheal mite & [13] \\
\hline Varroa jacobsoni & Ectoparasitic mite & {$[14]$} \\
\hline Tropilaelaps clareae & Ectoparasitic mite & [15] \\
\hline Deformed wing virus A & \multirow{8}{*}{ Viral pathogen } & \multirow{8}{*}{ [16-20] } \\
\hline Deformed wing virus B (VDV1) & & \\
\hline Acute bee paralysis virus & & \\
\hline Kashmir bee virus & & \\
\hline Israeli acute paralysis virus & & \\
\hline Chronic bee paralysis & & \\
\hline Sacbrood virus & & \\
\hline Black queen cell virus & & \\
\hline Nosema ceranae & \multirow{3}{*}{ Intestinal parasites } & \multirow{3}{*}[21,22]{} \\
\hline Nosema apis & & \\
\hline Nosema neumanni & & \\
\hline Ascosphaera apis & \multirow{2}{*}{ Fungal pathogen } & \multirow{2}{*}{ [23] } \\
\hline Aspergillus spp. & & \\
\hline Aethina tumida & Beekeeping pest & [24-30] \\
\hline
\end{tabular}




\subsection{Parasitic Mites}

Honey bee hives can be a suitable habitat for various mites (Acari), including nonparasitic, omnivorous, pollen-feeding species, and parasites. Out of the different mite species associated with honey bees, Varroa destructor, Acarapis woodi, Varroa jacobsoni and Tropilaelaps clareae are economically significant pests of honey bees, and their infestation may lead to the destruction of the beekeeping industry in many cases [31,32]. Varroa destructor is the most serious pest of honey bee colonies around the world, as it is an obligate parasite which is able to attack different developmental stages and castes of $A$. mellifera [33]. It is interesting to note that Varroa mites have been established in New Zealand since 2000, but as of yet, Australia is still Varroa-free [34]. Additionally, in Africa, African honey bees seem to survive despite the presence of Varoa destructor, as do the Africanized honey bees in South America [35]. It is well known that the ectoparasitic mite Varroa destructor switched hosts from Eastern honey bees (Apis cerana) to Western honey bees (Apis mellifera) [36]. Thus, the Western honey bee has shown more susceptibility than Apis cerana. This increased resistance of the Africanized honey bees against $V$. destructor may be explained with their more aggressive behavior than the Western honey bee $[37,38]$. The association of $V$. destructor with the Western honey bee has led to a significant reduction of honey bee colonies.

$V$. destructor feeds on the fat bodies from adult bees, but not with hemolymph as previously believed [39]. For drones, it has been demonstrated that reduced weight due to $V$. destructor has resulted in decreased flight performance and sperm production [40]. There have also been reports of impaired orientation and homing ability of foraging bees infested with mite parasites, where the affected bees needed more time to return to the colony or did not return at all [41].

Therefore, a moderate Varroa infestation is considered to be one of the major factors leading to reduction of honey bee colonies, due to its influence on reproductive capacity and the general fitness of the colony. Moderate-to-severe infestations have been observed, especially during the autumn, when the mite population increases whereas the host population decreases [42]. The damage threshold is not correlated exactly with the number of mites per colony but is highly variable, depending on the bee and brood population, the season and its role as a very efficient vector of several honey bee-associated viruses [43].

Typical control of $V$. destructor involves the use of strips treated with fluvalinate, a pyrethroid, which are placed in the hive during times of no honey production. Intensive use of these strips has resulted in resistance to pyrethroid insecticides in some parts of Europe [44], the United States [45], Israel [46], and Mexico [47]. The spread of pyrethroid resistance in Europe seems to follow the initial spread of the mite according to bee movement, which suggests that resistance evolved once and spread thereafter [48]. Coumaphos, an organophosphate insecticide, was soon introduced for emergency use after control problems with fluvalinate. However, resistance to coumaphos is already present in Florida, USA [49] and northern Italy [50]. In Minnesota, USA [51] and in Mexico [47], there have been reports of resistance to both pyrethroids and amitraz, an amidine.

Thus, the increased resistance of Varroa dectructor against various insecticides creates a precondition for additional difficulty in combating mites and seeking alternative approaches.

\subsection{Honey Bee-Associated Viruses}

About 24 honey bee-associated viruses have been identified in the Western honey bee (Apis mellifera) [52]. Some of them generally persist in the bee's body, without causing a disease or manifestation of any clinical signs. In general, virus infestations were not considered to be a significant problem to honey bee health. On the other hand, some viruses are more virulent and infective, and thus may cause a significant loss in honey bee colonies as well as a decline in honey bees' health and production [53]. Some viruses show pathogenicity only under certain favorable environmental conditions.

Varroa mites $V$. destructor are considered to be the main transmitter of many honey bee viruses: deformed wing virus (DWV); acute bee paralysis virus (ABPV), Kashmir bee virus (KBV), and Israeli 
acute paralysis virus (IAPV) [39,54]. Furthermore, three viruses in the transmission of which Varroa seems to play no significant role, namely, chronic bee paralysis virus (CBPV), sacbrood virus (SBV), and black queen cell virus (BQCV) are also frequently surveyed $[55,56]$. This fact allows to us think that Varroa mites alone are not the (only) cause of honey bee losses. The negative influence of $V$. destructor results from its role as a viral reservoir and a transmitter of some honey bee-associated viruses [33]; the mite promotes replication of honey bee viruses like DWV [57]. Due to its feeding behavior, the Varroa mite injects directly viruses in the hemolymph, which has been associated with oral or sexual transmission of these viruses [58].

\subsection{Microsporidia}

Microsporidia are fungal, obligate intracellular parasites, infectious to honey bees. Microsporidia are possibly the smallest single-cell organisms which have a true nucleus. The genus Nosema is a parasitic fungus infecting insects such as honey bees, bumble bees and silkworms. Until now, only two species of microsporidia, namely, Nosema ceranae and Nosema apis, have been reported to parasitize on adult honey bees [59]. In 2017, a new species of Nosema, named Nosema neumanni, in honey bees from Uganda was reported [22]. It has been established that $N$. apis is specific for the Western honey bee, Apis mellifera L., whilst the Asiatic bee, Apis cerana, harbors N. ceranae [60]. For a long time, it was believed that $N$. ceranae and N. apis were species-specific. Since the beginning of this millennium (mainly post 2003), many investigations have revealed that N. ceranae has switched hosts and has become the dominant species in many countries [61-65]. Thus, it has been suggested that N. ceranae is possibly more virulent than N. apis.

It has been well documented that microsporidia invade the midgut epithelial cells of worker bees, queens and drones [66]. Nosema has adverse effects on the bee colony. The negative effect of nosemosis at the colony level is connected with the productivity and survival of honey bee colonies, including adult bee longevity, queen bees, brood rearing, bee biochemistry, pollen collection and other bee behaviors [67].

In contrast to $N$. apis, which rarely leads to the death of a diseased colony, since its emergence as a novel pathogen of the Western honey bee A. mellifera, $N$. ceranae has been generally associated with heavily diseased honey bee colonies [21]. Considering N. ceranae as a potential factor in CCD, we may summarize that almost any given disease organism has to persist over time (i.e., there has to be an increase in larval/adult incidence of infection) before causing colony mortality, and generally, $N$. ceranae acts simultaneously with other pathogens. For example, N. ceranae has been reported to be persistent for over an 18-month period in the colony before causing colony weakness [68]. Therefore, the possibility that $N$. ceranae, alone or in combination with other factors, causes CCD is still left open.

Bicyclohexylammonium fumagillin, an antibiotic isolated from the fungus Aspergillus fumigatus, has been the only widely used treatment for nosemosis, or "nosema disease", in Western honey bees, Apis mellifera [69]. The practice of periodic fumagillin treatment leads to decreasing yet nearly constant exposure of multiple generations of bees and pathogens to the drug. Although this practice appears to provide an environment conducive to selection of fumagillin-resistant Nosema strains, N. apis does not seem to have developed resistance to the drug. However, studies have shown that $N$. ceranae can reestablish pretreatment prevalence 6 months after treatments are terminated [70]. Research on protein profiles of bees treated with fumagillin has confirmed our hypothesis that fumagillin affects bee physiology at concentrations that no longer suppress $N$. ceranae. Thus, the use of fumagillin may increase the prevalence of $N$. ceranae and may be a factor in the replacement of $N$. apis by N. ceranae in US apiaries [71]. Besides having negative effects on host physiology, fumagillin presents some other drawbacks, e.g., increased management costs and risks to human health through honey consumption, as drug residues may persist in the hive [72]. Therefore, new alternatives to hard chemicals for Nosema spp. management are needed and sought. 


\subsection{Small Hive Beetle}

The small hive beetle (SHB, Aethina tumida) is endemic to sub-Saharan Africa and alien for European honey bee pest [24]. During the last 25 years, SHBs were introduced into many countries worldwide, causing great damage to beekeeping as well as wild honey bee colonies [25]. The damages from SHBs occur when the honey bee population is insufficient to protect the honey combs from the scavenging beetle larvae [26]. Both adult and larval beetles are harmful to honey bee eggs and brood, but the larvae caused major damages as they funnel through comb with stored honey or pollen, damaging or destroying capping and comb [27]. Unlike wax moths, the SHB larvae do not necessarily damage the combs themselves, and do not produce extensive webbing. When large numbers of adult beetles defecate in the honey, they introduce yeasts, causing the honey to ferment and run out of the cells [28]. In this case, the queen bee may cease laying, and the entire colony may abscond. Weak colonies are particularly vulnerable to attack, but even strong colonies can be overwhelmed by large populations of beetles [24].

Beetles can create problems in cases when honey is removed from the hive, but not immediately extracted, i.e., beetles can invade the beekeeping room and quickly ruin a large portion of a honey harvest [29]. Honey contaminated by SHBs often is rejected by honey bees and is entirely unfit for human consumption [30].

\subsection{Synergistic Effects of Various Diseases and Parasites}

The interaction of Nosema spp. and viruses has been reported for bees co-infected with N. ceranae and chronic bee paralysis virus (CBPV) or DWV. One study showed that co-infection of bees with N. ceranae and CBPV led to increased replication of CBPV but did not result in mortality [18]. Costa et al. [73] found a significant negative correlation between N. ceranae spore load and DWV titer in midgut tissues of workers.

An interesting study has evaluated co-parasitism with Varroa (Varroa destructor) and Nosema (Nosema ceranae and Nosema apis) on honey bees (Apis mellifera L.) which have different defense levels [74]. The obtained results have shown that high-mite-mortality-rate (high-MMR) bees in the Nosema (-) group exhibited greater reductions in mean abundance of mites over time in comparison with low-mite-mortality-rate (low-MMR) bees, when inoculated with additional mites. However, high-MMR bees did not manage to reduce mite load as well as in the Nosema (-) group when fed with Nosema spores. As a whole, the study demonstrated differential mite mortality rates among different genotypes of bees, and also showed that Nosema infection inhibited the success of Varroa removal in high-MMR bees [74].

Other authors found considerable colony level variation regarding infection levels, and identified subtle differences between the microbiota of colonies with high infection levels and those with low infection levels [75]. Two exact sequence variants of Gilliamella, a core gut symbiont, previously associated with gut dysbiosis, were notably more abundant in bees from colonies with high Nosema loads in comparison with those with low Nosema loads.

An interesting study has been conducted to examine the association between Varroa destructor and DWV spreading from it in infected honey bees [76]. The study is a new approach to clarifying pathogen-parasite interactions in bees. The results obtained show that the experimental removal of increasing volumes of hemolymph from individual bees increases viral densities. The conducted research clearly demonstrates the defensive role of hemolymph in the bees and confirms that hemolymph has not only a bactericidal mode of action but also affects the regulation on viral replication in infected bees, which has been shown for the first time. The pathogen-parasite relationships observed in honey bees confirm their negative impact on colony losses [76].

Another interesting research study is related to a not so common symbiosis in bees [77]. The Varroa mite and DWV act in mutualistic symbiosis in infected honey bees, i.e., Varroa destructor vectored DWV, whereas the DWV-induced immunosuppression in honey bees is mediated by NF- $\mathrm{kB}$ signaling 
pathway, which facilitates mite feeding and reproduction. The decrease in the immune response of bees due to this symbiosis is another reason that leads to a significant weakening of bee colonies [77].

Other examples may be given about synergistic effects of various pathogens in honey bees, but we may conclude that they all lead to honey bee colony losses to a greater or lesser extent.

\section{Anthropogenic Direct Drivers Associated with Honey Bee Colony Decline}

In addition to different pest and diseases as direct natural drivers, there are many other drivers named anthropogenic, that lead to colony losses [78,79]. In many cases it is the interaction of these factors that leads to morbidity and mortality, and colony losses (Table 2). In this review, we will focus on the factors that are considered the most important.

Table 2. Environmental factors associated with honey bee colony losses.

\begin{tabular}{ccc}
\hline $\begin{array}{c}\text { Anthropogenic Direct Drivers } \\
\text { that Cause Honey Bee Decline }\end{array}$ & Impact on Honey Bee & References \\
\hline Pesticides & $\begin{array}{c}\text { High rate of mortality, alteration of } \\
\text { different biological processes }\end{array}$ & [80-83] \\
Climate change & $\begin{array}{c}\text { Alteration of honey bee behavior, } \\
\text { physiology and distribution, } \\
\text { induced changes in flora for honey } \\
\text { bees vitality }\end{array}$ & [84] \\
\hline Introduction of alien species & $\begin{array}{c}\text { Competition for food resources, } \\
\text { decline of indigenous species, } \\
\text { alteration of the new habitat }\end{array}$ & [85-88] \\
\hline Genetically Modified Organisms & $\begin{array}{c}\text { Alteration bees foraging behavior } \\
\text { (GMOs) crop }\end{array}$ & [89] \\
\hline Land use and management & $\begin{array}{c}\text { Habitat and forage loss, honey bee } \\
\text { and wild bee competition }\end{array}$ & {$[$ [79,90] } \\
\hline Bee management & $\begin{array}{c}\text { Hybridity of honey bees, } \\
\text { migratory pollination }\end{array}$ & {$[91-94]$} \\
\hline Environmental pollution & $\begin{array}{c}\text { Imbalance in homeostasis, } \\
\text { weakening of the immune system }\end{array}$ & {$[95]$} \\
\hline Interactions between drivers & In many cases poorly studied & {$[96-105]$} \\
\hline
\end{tabular}

\subsection{Pesticides}

In recent decades, beekeepers have begun to use agrochemical pesticides not only for many crops, but in forests and other environments for the control of insect pests [106,107].

Pesticides are toxic chemicals with a specific mode of action, most often affecting a specific metabolic pathway in an organism [108]. Pesticides are applied via different pathways over the crop-sprays, seed coatings etc. [109]. The exposure of bees to pesticides is through ingestion of residues found in the pollen and nectar of contaminated plants (crop plants or the weeds around the fields) [110]. Insecticides pose the greatest danger to bees [80]. For this reason, beekeepers should be careful when using them near hives. In many countries, it is customary to inform beekeepers before treating crops in order to avoid their toxic effects on bees. These generally accepted rules are not observed in every country, which leads to mass mortality in bees and even the destruction of entire apiaries.

In recent years, the application of a new generation of pesticides-neonicotinoids-has been widely discussed among the scientific and beekeeping communities. They are used worldwide and are widely used for plant protection (crops, vegetables, fruits), veterinary products, and biocides to invertebrate pest control in fish farming [109]. Neonicotinoids represent a neurotoxic compound and their impact is more noticeable in insects than in mammals [111]. Their neurotoxic action is expressed 
as an agonist at nicotinic acetylcholine receptors (nAChRs) on the postsynaptic membrane, which plays a role in many cognitive processes [112].

One of the main marketed neonicotinoids is imidacloprid [113]. This neonicotinoid has various negative impacts on different biological processes in honey bees [81-83]. A recent study has shown that imidacloprid is involved in the reduction in protein biosynthesis and the decrease in the level of proteolytic activity (proteases) [114]. Taking into account the high protein content in royal jelly, this protein reduction is affected extremely adversely by the diet in larvae and queen, i.e., there is a subsequent decrease in honey bee populations [113]. In addition, it has been suggested that imidacloprid has a negative effect on antioxidant protection in young bees [115] as well as reduction in sperm motility (active mitochondria and sperm viability) [116].

These studies have shown the negative role of neonicotinoids on honey bee health and survival, which raises serious objections to their widespread use in agriculture.

\subsection{Climate Change}

Climate change may alter the synchrony between plant flowering and pollinator flight periods. Phenological mismatches probably contribute to pollinator losses that subsequently disrupt pollination of plants [117]. Climate is a crucial factor determining temperature and humidity. Humidity in hives must be maintained as low as possible, while the temperature of the brood must be maintained at $34^{\circ} \mathrm{C}$, and in winter the core temperature of the hive must not fall below $13^{\circ} \mathrm{C}$ [118]. This is very important, and honey bee colonies must have sufficient access to carbohydrates to maintain these temperatures and survive. Extended periods of cold or wet weather or depletion of food sources can also have a negative impact on honey bee colony health. These can restrain flying activity and limit nectar and pollen supplies to the hive. In contrast to low temperature, if the brood temperature increases above $34.5^{\circ} \mathrm{C}$, bees display behavioral differences combined with learning and memory difficulties [119].

The effect of weather on bee colonies as a major factor in CCD has been reported in a survey of honey bee colony losses in the USA [120]. CCD has been linked to changes in bee habitats and malnutrition, both of which are indirectly caused by climate change. Moreover, climate change may allow invasive species to invade bee hives, causing disruption and further decline in bee populations $[121,122]$.

\subsection{Environmental Pollution}

Honey bees interact with the environment especially while collecting pollen and nectar for feeding. Thus, they come into contact with some chemical substances and waste from the environment. In nature, waste and toxic substances (generally industrial gases, exhaust gases from vehicles, pesticides and insecticides) are absorbed and stored by plants. The largest part of air pollution is caused by anthropological factors (urbanization, industrialization, energy generation, mobile sources and other pollutants). One of the most important consequences of air pollution is heavy metal pollution [123,124]. Various heavy metal cations such as cadmium, cobalt, copper, zinc, lead, nickel and mercury are known to adversely affect both pollen (directly) and also the honey bees that feed on it (indirectly) $[125,126]$. Since bees collect pollen from different kinds of flowers, heavy metals found in large quantities within affected plants cause increased concentration of toxic heavy metals in bees' bodies and poison the latter. That is why honey bees and honey bee products are used as bioindicators of environmental pollution with heavy metals $[123,127,128]$.

\subsection{Bee Management}

Specific peculiarities of beekeeping can be the direct cause or a supplement to the complex of stressors that can contribute to colony breakdown. These include artificial, unilateral feeding, use of antibiotics, acaricides and insecticides in hives, exposure to adverse temperatures and temperature fluctuations, infections and parasites, overexploitation of bee products, as well as unreliable sources of bees and queens $[129,130]$. One-sided selection of the honey bee results in genetic erosion in the 
species population and a lack of resistance to infectious diseases, mites, beekeeping acaricides applied in hives, etc. [130,131].

A pan-European epidemiological study aimed to clarify the role of beekeepers on honey bee losses [132]. The authors concluded that honey bees kept by professional beekeepers never showed signs of disease, unlike apiaries from hobbyist beekeepers that had symptoms of bacterial infection and heavy Varroa infestation. Moreover, they claimed that beekeepers' experience and apicultural practices are the major drivers of honey bee colony losses. To avoid these shortcomings in beekeeping, it is necessary to conduct trans-national monitoring schemes and keep improving beekeeper training [132].

Artificial feeding of bees is often necessary due to overcrowding in conditions of prolonged cold and rainy weather [133]. Feeding is found to be deficient in areas with intensive agricultural production, where the so-called stress from a monotonous or "monocultural" diet is observed [96]. This refers to the continuous foraging of bees on crops in mass flowering, grown in large fields, such as sunflower or rapeseed, and acacia, where the goal is honey production or just pollination of plants. Other factors related to insufficient nutrition include low-nutrient pollen and nectar, as well as certain plant species, including crops and flowers containing substances which are natural but toxic to bees. This is the case for the amygdalin glycoside found in almond flowers [134,135].

Pollen is one of the most important food sources for the proper development and functioning of honey bee colonies. Protein supplements are usually used in early spring to stimulate feeding and in mid-early autumn in order to successfully overwinter bee colonies. It is interesting to note that the addition of small amounts of pollen into protein supplements increases the resilience of honey bee colonies against DWV and Nosema infection [136]. Moreover, seasonal pollens are very important for honey bee feeding and development during their annual cycle [137]. For this reason, it is necessary to plan the presence of pollen annually, and in case of seasonal deficiency in nature, it is necessary to provide additional feeding to the bee colonies. Honey bee nutrition is also an important factor for increasing the resistance of honey bee colonies against various pathogens [138]. Proper and balanced nutrition throughout the year is a prerequisite for the effective function of the immune system at both the individual and social level. Consistently improving nutrition is a necessary condition for higher sustainability and resistance against pathogens (for example Varroa mites and honey bee-associated viruses) and diseases.

It is well known that, in most countries, large numbers of hives are transported by truck to multiple locations to pollinate seasonal fields and orchards. Transportation exposes colonies to many challenging stressors. The ecological conditions to which a hive is acclimated prior to transportation are often quite different from those of the destination. Bees are moved between locations at highway speeds and deployed in fields and orchards prior to the bloom. After transportation bees are exposed to changes in temperature, day length, and nutrient supplementation, which can result in increased foraging activity and brood production earlier than what would have occurred before relocation and in agricultural environments prior to floral bloom with low availability of resources [139]. Although transportation has been noted as a factor likely contributing to colony loss, the focus has been on changing forage quality and consistency rather than on stress endured during transportation [140]. Transportation stress has received less attention due to the difficulties of collecting data during shipping, yet it needs to be taken into consideration.

During transportation, colonies experience a number of stressors, including confinement, increased variation in temperature, air pressure, and vibration, frequent changes in elevation and latitude. Insufficient ventilation poses a serious risk of mortality due to overheating. Low-temperature stress also affects the bees, though less obviously. Transported colonies may experience extended periods of sub-lethal chill stress and loss of thermoregulation (LT), which affects long-term colony survival without proximate mortality by inducing developmental defects in new brood [141,142]. 


\subsection{GMO Crops}

Soybean and cotton varieties, followed by corn, with genetically incorporated genes for insecticide synthesis and herbicide tolerance, were first introduced in the USA in 1996. In 2007, 113 million hectares in different parts of the world (EU was among the exceptions) were sown with genetically modified crops [143]. With the expansion of the area planted with these crops, concerns have arisen about the safety of bees and other pollinators. Researchers have conducted a number of studies, involving dozens of plant species carrying Bt genes of Bacillus thuringiensis for resistance to insect pests $[80,144,145]$. It has been observed that there are no direct lethal effects of insect-resistant (IR) crops (e.g., producing Bacillus thuringiensis (Bt) toxins) on honey bees or other Hymenoptera, but some sub-lethal effects on honey bee behavior have been determined [139]. The impact of GMOs on honey bee health is contradictory. Some researchers have found that ingestion of high concentrations of Bt-toxins affected honey bee behavior [146], while others did not observe differences in the behavior and learning in honey bees [147]. There was no effect at lower toxin concentrations, such as those found in other transgenic varieties [148]. The presence of toxins in GMOS crops leads to reduced larval survival and body mass, and to increased developmental time in honey bees [149]. On the other hand, the introduction of varieties tolerant to certain herbicides and clean field technology have created conditions for growing maize, sunflower, etc., in the absence of weed vegetation in the crops. Since weeds are an alternative source of foraging, the widespread use of technology is considered to be one of the contributing factors to the starvation of bees-both wild and cultivated.

\subsection{Interactions between Different Drivers}

Except that multiple pressures individually impact the honey bee health, there are many evidences about the potential synergistic or additive effects among some drivers that leading to an overall negative impact on honey bee health and survival $[12,150]$. The most significant interactions among drivers are pointed out: 1 . climate change and land-use-for instance, due to global warming, a pollinator species may migrate to a new geographical area, thus increasing the variety of pollinators of recipient region [97]. In many cases, this migration is unfavorable for the local fauna due to competition for food resources or transfer of various pests and diseases [98]; 2. pathogens and chemicals in the environment-the impact of pathogens and insecticides is another form of synergistic effect between drivers. Many authors have observed increased larval or worker honey bee mortality due to the additive or synergistic interactions between sub-lethal doses of neonicotinoid, infection by the Nosema ceranae and (BQCV) [99-101]; 3. bee nutrition and stress from disease and pesticides-honey bee colonies need proper and balanced nutrition to maintain their development and reproduction [102]. A large number of direct anthropogenic drivers produce alterations in diversity and may even lead to the extinction of many flowering plants which are the main food sources for honey bees $[103,104]$. These anthropogenic interventions may lead to malnutrition, i.e., reducing activity of immune system and potentially the function of some important detoxification enzymes; there is an elevated risk of the individual and combined impact of pesticides and pathogens on honey bees [96-105]. From what has been said so far, it is clear that the interaction between anthropogenic direct and natural direct drivers may represent a serious threat to honey bee health and survival.

\section{Conclusions}

Recent investigations have reported an increase in colony losses in some regions and have stimulated investment in more coordinated monitoring of bees and research on the impact of pests and diseases, bee diversity, bee-keeping practices and bee foraging environments on bee vitality. Factors such as land management and environmental conditions further affect the availability and quality of food sources as well as the conditions in the hive. Effective management of bee colonies under changing situations also depends on beekeeping practices and bee selection. All these diverse factors can affect bees' vitality and ability to overcome pests and diseases. 
Author Contributions: All authors have equally contributed to the idea of this review. P.H. and B.N. prepared the original draft with considerable contributions from N.P. and R.S. All authors have substantially contributed to the writing of the final text. Moreover, all authors have read and agreed to the published version of the manuscript.

Funding: This work was funded by the National Scientific Fund of the Bulgarian Ministry of Education and Science, (grant numbers 06/10 17.12.2016). The funders had no role in study design, data collection and analysis, decision to publish, or preparation of the manuscript.

Conflicts of Interest: The authors declare that they have no conflict of interest.

\section{References}

1. Neumann, P.; Carreck, N.L. Honey bee colony losses. J. Apic. Res. 2010, 49, 1-6. [CrossRef]

2. Taniguchi, T.; Kita, Y.; Matsumoto, T.; Kimura, K. Honeybee Colony Losses during 2008 2010 Caused by Pesticide Application in Japan. J. Apic. 2012, 27, 15-27.

3. Liu, Z.; Chen, C.; Niu, Q.; Qi, W.; Yuan, C.; Su, S.; Liu, S.; Zhang, Y.; Zhang, X.; Ji, T.; et al. Survey results of honey bee (Apis mellifera) colony losses in China (2010-2013). J. Apic. Res. 2016, 55, 29-37. [CrossRef]

4. Awad, A.M.; Owayss, A.A.; Alqarni, A.S. Performance of two honey bee subspecies during harsh weather and Acacia gerrardii nectar-rich flow. Sci. Agric. 2017, 74, 474-480. [CrossRef]

5. Al-Ghamdi, A.; Adgaba, N.; Getachew, A.; Tadesse, Y. New approach for determination of an optimum honeybee colony's carrying capacity based on productivity and nectar secretion potential of bee forage species. Saudi J. Biol. Sci. 2016, 23, 92-100. [CrossRef] [PubMed]

6. Potts, S.G.; Roberts, S.P.; Dean, R.; Marris, G.; Brown, M.A.; Jones, R.; Neumann, P.; Settele, J. Declines of managed honey bees and beekeepers in Europe. J. Apic. Res. 2010, 49, 15-22. [CrossRef]

7. Aston, D. Honey bee winter loss survey for England, 2007-2008. J. Apic. Res. 2010, 49, 111-112. [CrossRef]

8. Topolska, G.; Gajda, A.; Pohorecka, K.; Bober, A.; Kasprzak, S.; Skubida, M.; Semkiw, P. Winter colony losses in Poland. J. Apic. Res. 2010, 49, 126-128. [CrossRef]

9. Gray, A.; Adjlane, N.; Arab, A.; Ballis, A.; Brusbardis, V.; Charrière, J.D.; Chlebo, R.; Coffey, M.F.; Cornelissen, B.; Amaro da Costa, C.; et al. Honey bee colony winter loss rates for 35 countries participating in the COLOSS survey for winter 2018-2019, and the effects of a new queen on the risk of colony winter loss. J. Apic. Res. 2020, 59, 744-751. [CrossRef]

10. Xu, P.; Shi, M.; Chen, X.X. Antimicrobial peptide evolution in the Asiatic honey bee Apis cerana. PLoS ONE 2009, 4, e4239. [CrossRef]

11. Clermont, A.; Pasquali, M.; Eickermann, M.; Kraus, F.; Hoffmann, L.; Beyer, M. Virus status, varroa levels and survival of 20 managed honey bee colonies monitored in Luxembourg between summer 2011 and spring 2013. J. Apic. Sci. 2015, 59, 59-73. [CrossRef]

12. Mõtus, K.; Raie, A.; Orro, T.; Chauzat, M.-P.; Viltrop, A. Epidemiology, risk factors and varroa mite control in the Estonian honey bee population. J. Apic. Res. 2016, 55, 396-412. [CrossRef]

13. Garrido-Bailón, E.; Bartolomé, C.; Prieto, L.; Botías, C.; Martínez-Salvador, A.; Meana, A.; Martín-Hernández, R.; Higes, M. The prevalence of Acarapis woodi in Spanish honey bee (Apis mellifera) colonies. Exp. Parasitol. 2012, 132, 530-536.

14. Roberts, J.; Anderson, D.; Tay, W. Multiple host shifts by the emerging honeybee parasite, Varroa jacobsoni. Mol. Ecol. 2015, 24, 2379-2391. [CrossRef]

15. Waghchoure-Camphor, E.S.; Martin, S.J. Population changes of Tropilaelaps clareae mites in Apis mellifera colonies in Pakistan. J. Apic. Res. 2009, 48, 46-49. [CrossRef]

16. Posada-Florez, F.; Childers, A.K.; Heerman, M.C.; Egekwu, N.I.; Cook, S.C.; Chen, Y.; Evans, J.D.; Ryabov, E.V. Deformed wing virus type A, a major honey bee pathogen, is vectored by the mite Varroa destructor in a non-propagative manner. Sci. Rep. 2019, 9, 12445. [CrossRef]

17. De Miranda, J.R.; Cordoni, G.; Budge, G. The acute bee paralysis virus-Kashmir bee virus-Israeli acute paralysis virus complex. J. Invertebr. Pathol. 2010, 103, S30-S47. [CrossRef]

18. Toplak, I.; Jamnikar Ciglenečki, U.; Aronstein, K.; Gregorc, A. Chronic bee paralysis virus and Nosema ceranae experimental co-infection of winter honey bee workers (Apis mellifera L.). Viruses 2013, 5, 2282-2297. [CrossRef] 
19. Li, J.; Wang, T.; Evans, J.D.; Rose, R.; Zhao, Y.; Li, Z.; Li, J.; Huang, S.; Heerman, M.; Rodríguez-García, C.; et al. The phylogeny and pathogenesis of Sacbrood virus (SBV) infection in European honey bees, Apis mellifera. Viruses 2019, 11, 61. [CrossRef]

20. Spurny, R.; Přidal, A.; Pálková, L.; Kiem, H.K.T.; de Miranda, J.R.; Plevka, P. Virion structure of black queen cell virus, a common honeybee pathogen. J. Virol. 2017, 91, e02100-16. [CrossRef]

21. Vejsnaes, F.; Neilsen, S.L.; Kryger, P. Factors involved in the recent increase in colony losses in Denmark. J. Apic. Res. 2010, 49, 109-110. [CrossRef]

22. Chemurot, M.; De Smet, L.; Brunain, M.; De Rycke, R.; de Graaf, D.C. Nosema neumanni n. sp. (Microsporidia, Nosematidae), a new microsporidian parasite of honeybees, Apis mellifera in Uganda. Eur. J. Protistol. 2017, 61, 13-19. [CrossRef] [PubMed]

23. Sarwar, M. Fungal diseases of honey bees (Hymenoptera: Apidae) that induce considerable losses to colonies and protocol for treatment. Int. J. Zool. Stud. 2016, 1, 8-13.

24. Neumann, P.; Pettis, J.S.; Schäfer, M.O. Quo vadis Aethina tumida? Biology and control of small hive beetles. Apidologie 2016, 47, 427-466. [CrossRef]

25. Schäfer, M.O.; Cardaio, I.; Cilia, G.; Cornelissen, B.; Crailsheim, K.; Formato, G.; Lawrence, A.K.; Le Conte, Y.; Mutinelli, F.; Nanetti, A.; et al. How to slow the global spread of small hive beetles, Aethina tumida. Biol. Invasions 2019, 21, 1451-1459. [CrossRef]

26. Neumann, P.; Spiewok, S.; Pettis, J.; Radloff, S.E.; Spooner-Hart, R.; Hepburn, R. Differences in absconding between African and European honeybee subspecies facilitate invasion success of small hive beetles. Apidologie 2018, 49, 527-537. [CrossRef]

27. Huang, Q.; Lopez, D.; Evans, J.D. Shared and unique microbes between Small hive beetles (Aethina tumida) and their honey bee hosts. Microbiol. Open 2019, 8, e899. [CrossRef]

28. Mustafa, S.G.; Spiewok, S.; Duncan, M.; Spooner-Hart, R.; Rosenkranz, P. Susceptibility of small honey bee colonies to invasion by the small hive beetle, Aethina tumida (Coleoptera, Nitidulidae). J. Appl. Entomol. 2014, 138, 547-550. [CrossRef]

29. Ellis, J.D.; Hepburn, H.R. An ecological digest of the small hive beetle (Aethina tumida), a symbiont in honey bee colonies (Apis mellifera). Insectes Sociaux 2006, 53, 8-19. [CrossRef]

30. Bernier, M.; Fournier, V.; Eccles, L.; Giovenazzo, P. Control of Aethina tumida (Coleoptera: Nitidulidae) using in-hive traps. Can. Entomol. 2015, 147, 97-108. [CrossRef]

31. Sammataro, D.; Gerson, U.; Needham, G. Parasitic mites of honey bees: Life history, implications, and impact. Annu. Rev. Entomol. 2000, 45, 519-548. [CrossRef] [PubMed]

32. Dhooria, M.S. Parasitic Mites on Honeybees. In Fundamentals of Applied Acarology; Springer: Singapore, 2016.

33. Shen, M.; Cui, L.; Ostiguy, N.; Cox-Foster, D. Intricate transmission routes and interactions between picorna-like viruses (Kashmir bee virus and sacbrood virus) with the honeybee host and the parasitic varroa mite. J. Gen. Virol. 2005, 86, 2281-2289. [CrossRef] [PubMed]

34. Iwasaki, J.M.; Barratt, B.I.; Lord, J.M.; Mercer, A.R.; Dickinson, K.J. The New Zealand experience of varroa invasion highlights research opportunities for Australia. Ambio 2015, 44, 694-704. [CrossRef] [PubMed]

35. Strauss, U.; Dietemann, V.; Human, H.; Crewe, R.M.; Pirk, C.W. Resistance rather than tolerance explains survival of savannah honeybees (Apis mellifera scutellata) to infestation by the parasitic mite Varroa destructor. Parasitology 2016, 143, 374-387. [CrossRef]

36. Beaurepaire, A.L.; Truong, T.A.; Fajardo, A.C.; Dinh, T.Q.; Cervancia, C.; Moritz, R.F. Host specificity in the honeybee parasitic mite, Varroa spp. in Apis mellifera and Apis cerana. PLoS ONE 2015, 10, e0135103. [CrossRef]

37. Medina Flores, C.A.; Guzmán Novoa, E.; Hamiduzzaman, M.; Aréchiga Flores, C.F.; López Carlos, M.A. Africanized honey bees (Apis mellifera) have low infestation levels of the mite Varroa destructor in different ecological regions in Mexico. Genet. Mol. Res. 2014, 13, 7282-7293. [CrossRef]

38. Oddie, M.; Büchler, R.; Dahle, B.; Kovacic, M.; Le Conte, Y.; Locke, B.; de Miranda, J.R.; Mondet, F.; Neumann, P. Rapid parallel evolution overcomes global honey bee parasite. Sci. Rep. 2018, 8, 7704. [CrossRef]

39. Ramsey, S.D.; Ochoa, R.; Bauchan, G.; Gulbronson, C.; Mowery, J.D.; Cohen, A.; Lim, D.; Joklik, J.; Cicero, J.M.; Ellis, J.D.; et al. Varroa destructor feeds primarily on honey bee fat body tissue and not hemolymph. Proc. Natl. Acad. Sci. USA 2019, 116, 1792-1801. [CrossRef]

40. Rinkevich, F.D.; Danka, R.G.; Healy, K.B. Influence of Varroa Mite (Varroa destructor) Management Practices on Insecticide Sensitivity in the Honey Bee (Apis mellifera). Insects 2017, 8, 9. [CrossRef] 
41. Peck, D.T.; Smith, M.L.; Seeley, T.D. Varroa destructor Mites Can Nimbly Climb from Flowers onto Foraging Honey Bees. PLoS ONE 2016, 11, e0167798. [CrossRef]

42. Oddie, M.; Dahle, B.; Neumann, P. Norwegian honey bees surviving Varroa destructor mite infestations by means of natural selection. PeerJ 2017, 5, e3956. [CrossRef] [PubMed]

43. Glenny, W.; Cavigli, I.; Daughenbaugh, K.F.; Radford, R.; Kegley, S.E.; Flenniken, M.L. Honey bee (Apis mellifera) colony health and pathogen composition in migratory beekeeping operations involved in California almond pollination. PLoS ONE 2017, 12, e0182814. [CrossRef] [PubMed]

44. Floris, I.; Cabras, P.; Garau, V.L.; Minelli, E.V.; Satta, A.; Troullier, J. Persistence and effectiveness of pyrethroids in plastic strips against Varroa jacobsoni (Acari: Varroidae) and mite resistance in a Mediterranean area. J. Econ. Entomol. 2001, 94, 806-810. [CrossRef] [PubMed]

45. Macedo, P.A.; Wu, J.; Ellis, M.D. Using inert dusts to detect and assess varroa infestations in honey bee colonies. J. Apic. Res. 2002, 41, 3-7. [CrossRef]

46. Mozes-Koch, R.; Slabezki, Y.; Efrat, H.; Kalev, H.; Kamer, Y.; Yakobson, B.A.; Dag, A. First detection in Israel of fluvalinate resistance in the varroa mite using bioassay and biochemical methods. Exp. Appl. Acarol. 2000, 24, 35-43. [CrossRef] [PubMed]

47. Rodríguez-Dehaibes, S.R.; Otero-Colina, G.; Sedas, V.P.; Jiménez, J.A.V. Resistance to amitraz and flumethrin in Varroa destructor populations from Veracruz, Mexico. J. Apic. Res. 2005, 44, 124-125. [CrossRef]

48. Büchler, R.; Berg, S.; Le Conte, Y. Breeding for resistance to Varroa destructor in Europe. Apidologie 2010, 41, 393-408. [CrossRef]

49. Elzen, P.J.; Westervelt, D. Detection of coumaphos resistance in Varroa destructor in Florida. Am. Bee J. 2002, 142, 291-292.

50. Spreafico, M.; Eördegh, F.R.; Bernardinelli, I.; Colombo, M. First detection of strains of Varroa destructor resistant to coumaphos. Results of laboratory tests and field trials. Apidologie 2001, 32, 49-55. [CrossRef]

51. Elzen, P.J.; Baxter, J.R.; Spivak, M.; Wilson, W.T. Control of Varroa jacobsoni Oud. resistant to fluvalinate and amitraz using coumaphos. Apidologie 2000, 31, 437-441. [CrossRef]

52. Gisder, S.; Genersch, E. Special issue: Honey bee viruses. Viruses 2015, 7, 5603-5608. [CrossRef]

53. Genersch, E.; Aubert, M. Emerging and re-emerging viruses of the honey bee (Apis mellifera L.). Vet. Res. 2010, 41, 54. [CrossRef] [PubMed]

54. Locke, B. Natural Varroa mite-surviving Apis mellifera honeybee populations. Apidologie 2016, 47, 467-482. [CrossRef]

55. Tentcheva, D.; Gauthier, L.; Zappulla, N.; Dainat, B.; Cousserans, F.; Colin, M.E.; Bergoin, M. Prevalence and seasonal variations of six bee viruses in Apis mellifera L. and Varroa destructor mite populations in France. Appl. Environ. Microbiol. 2004, 70, 7185-7291. [CrossRef]

56. Nielsen, S.L.; Nicolaisen, M.; Kryger, P. Incidence of acute bee paralysis virus, black queen cell virus, chronic bee paralysis virus, deformed wing virus, Kashmir bee virus and sacbrood virus in honey bees (Apis mellifera) in Denmark. Apidologie 2008, 39, 310-314. [CrossRef]

57. Levin, S.; Sela, N.; Chejanovsky, N. Two novel viruses associated with the Apis mellifera pathogenic mite Varroa destructor. Sci. Rep. 2016, 6, 37710. [CrossRef]

58. Francis, R.M.; Nielsen, S.L.; Kryger, P. Patterns of viral infection in honey bee queens. J. Gen. Virol. 2013, 94, 668-676. [CrossRef]

59. Paris, L.; El Alaoui, H.; Delbac, F.; Diogon, M. Effects of the gut parasite Nosema ceranae on honey bee physiology and behavior. Curr. Opin. Insect. Sci. 2018, 26, 149-154. [CrossRef]

60. Fries, I.; Feng, F.; Da Silva, A.; Slemenda, S.B.; Pieniazek, N.J. Nosema ceranae n. sp. (Microspora, Nosematidae), morphological and molecular characterization of a microsporidian parasite of the Asian honey bee Apis cerana (Hymenoptera, Apidae). Eur. J. Protistol. 1996, 32, 356-365. [CrossRef]

61. Klee, J.; Besana, A.M.; Genersch, E.; Gisder, S.; Nanetti, A.; Tam, D.Q.; Chinh, T.X.; Puerta, F.; Ruz, J.M.; Kryger, P.; et al. Widespread dispersal of the microsporidian Nosema ceranae, an emergent pathogen of the western honey bee, Apis mellifera. J. Invertebr. Pathol. 2007, 96, 1-10. [CrossRef]

62. Paxton, R.J.; Klee, J.; Korpela, S.; Fries, I. Nosema ceranae has infected Apis mellifera in Europe since at least 1998 and may be more virulent than Nosema apis. Apidologie 2007, 38, 558-565. [CrossRef]

63. Chen, Y.P.; Evans, J.D.; Smith, I.B.; Pettis, J.S. Nosema ceranae is a long-present and widespread microsporidean infection of the European honey bee (Apis mellifera) in the United States. J. Invertebr. Pathol. 2008, 97, 186-188. [CrossRef] [PubMed] 
64. Invernizzi, C.; Abud, C.; Tomasco, I.H.; Harriet, J.; Ramallo, G.; Campa, J.; Katz, H.; Gardiol, G.; Mendoza, Y. Presence of Nosema ceranae in honeybees (Apis mellifera) in Uruguay. J. Invertebr. Pathol. 2009, 101, 150-153. [CrossRef]

65. Stevanovic, J.; Stanimirovic, Z.; Genersch, E.; Kovacevic, S.R.; Ljubenkovic, J.; Radakovic, M.; Aleksic, N. Dominance of Nosema ceranae in honey bees in the Balkan countries in the absence of symptoms of colony collapse disorder. Apidologie 2011, 42, 49-58. [CrossRef]

66. Papini, R.; Mancianti, F.; Canovai, R.; Cosci, F.; Rocchigiani, G.; Benelli, G.; Canale, A. Prevalence of the microsporidian Nosema ceranae in honeybee (Apis mellifera) apiaries in Central Italy. Saudi J. Biol. Sci. 2017, 24, 979-982. [CrossRef] [PubMed]

67. Botías, C.; Martín-Hernández, R.; Barrios, L.; Meana, A.; Higes, M. Nosema spp. infection and its negative effects on honey bees (Apis mellifera iberiensis) at the colony level. Vet. Res. 2013, 44, 25. [CrossRef]

68. Higes, M.; Martín-Hernandez, R.; Garrido-Bailon, E.; Gonzalez-Porto, A.V.; García-Palencia, P.; Meana, A.; Del Nozal, M.J.; Mayo, R.; Bernal, J.L. Honey bee colony collapse due to Nosema ceranae in professional apiaries. Environ. Microbiol. Rep. 2009, 1, 110-113. [CrossRef] [PubMed]

69. Higes, M.; Nozal, M.J.; Alvaro, A.; Barrios, L.; Meana, A.; Martín-Hernández, R.; Bernal, J.L.; Bernal, J. The stability and effectiveness of fumagillin in controlling Nosema ceranae (Microsporidia) infection in honey bees (Apis mellifera) under laboratory and field conditions. Apidologie 2011, 42, 364-377. [CrossRef]

70. Pajuelo, A.G.; Torres, C.; Bermejo, F.J.O. Colony losses: A double blind trial on the influence of supplementary protein nutrition and preventative treatment with fumagillin against Nosema ceranae. J. Apic. Res. 2008, 47, 84-86. [CrossRef]

71. Huang, W.F.; Solter, L.F.; Yau, P.M.; Imai, B.S. Nosema ceranae escapes fumagillin control in honey bees. PLoS Pathog. 2013, 9, e1003185. [CrossRef]

72. Van den Heever, J.P.; Thompson, T.S.; Curtis, J.M.; Pernal, S.F. Stability of dicyclohexylamine and fumagillin in honey. Food Chem. 2015, 179, 152-158. [CrossRef] [PubMed]

73. Costa, C.; Tanner, G.; Lodesani, M.; Maistrello, L.; Neumann, P. Negative correlation between Nosema ceranae spore loads and deformed wing virus infection levels in adult honey bee workers. J. Invertebr. Pathol. 2011, 108, 224-225. [CrossRef] [PubMed]

74. Bahreini, R.; Currie, R.W. The influence of Nosema (Microspora: Nosematidae) infection on honey bee (Hymenoptera: Apidae) defense against Varroa destructor (Mesostigmata: Varroidae). J. Invertebr. Pathol. 2015, 132, 57-65. [CrossRef] [PubMed]

75. Rubanov, A.; Russell, K.A.; Rothman, J.A.; Nieh, J.C.; McFrederick, Q.S. Intensity of Nosema ceranae infection is associated with specific honey bee gut bacteria and weakly associated with gut microbiome structure. Sci. Rep. 2019, 9, 3820. [CrossRef]

76. Annoscia, D.; Brown, S.P.; Di Prisco, G.; De Paoli, E.; Del Fabbro, S.; Frizzera, D.; Zanni, V.; Galbraith, D.A.; Caprio, E.; Grozinger, C.M.; et al. Haemolymph removal by Varroa mite destabilizes the dynamical interaction between immune effectors and virus in bees, as predicted by Volterra's model. Proc. R. Soc. B. 2019, 286, 28620190331. [CrossRef]

77. Di Prisco, G.; Annoscia, D.; Margiotta, M.; Ferrara, R.; Varricchio, P.; Zanni, V.; Caprio, E.; Nazzi, F.; Pennacchio, F. A mutualistic symbiosis between a parasitic mite and a pathogenic virus undermines honey bee immunity and health. Proc. Natl. Acad. Sci. USA 2016, 113, 3203-3208. [CrossRef]

78. Kovács-Hostyánszki, A.; Espíndola, A.; Vanbergen, A.J.; Settele, J.; Kremen, C.; Dicks, L.V. Ecological intensification to mitigate impacts of conventional intensive land use on pollinators and pollination. Ecol. Lett. 2017, 20, 673-689. [CrossRef]

79. IPBES. The Assessment Report of the Intergovernmental Science-Policy Platform on Biodiversity and Ecosystem Services on Pollinators, Pollination and Food Production; Potts, S.G., Imperatriz-Fonseca, V.L., Ngo, H.T., Eds.; Secretariat of the Intergovernmental Science-Policy Platform on Biodiversity and Ecosystem Services: Bonn, Germany, 2016; p. 552.

80. Al Naggar, Y.; Codling, G.; Vogt, A.; Naiem, E.; Mona, M.; Seif, A.; Giesy, J.P. Organophosphorus insecticides in honey, pollen and bees (Apis mellifera L.) and their potential hazard to bee colonies in Egypt. Ecotoxicol. Environ. Saf. 2015, 114, 1-8. [CrossRef]

81. Piiroinen, S.; Goulson, D. Chronic neonicotinoid pesticide exposure and parasite stress differentially affects learning in honey bees and bumblebees. Proc. Royal Soc. B. 2016, 283, 20160246. [CrossRef] 
82. Schneider, C.W.; Tautz, J.; Gruenewald, B.; Fuchs, S. RFID tracking of sublethal effects of two neonicotinoids insecticides on the foraging behavior of Apis mellifera. PLoS ONE 2012, 7, e30023. [CrossRef]

83. Goulson, D. Review: An overview of the environmental risks posed by neonicotinoid insecticides. J. Appl. Ecol. 2013, 50, 977-987. [CrossRef]

84. Le Conte, Y.; Navajas, M. Climate change: Impact on honey bee populations and diseases. Rev. Sci. Tech. OIE J. 2008, 27, 499-510.

85. Laurino, D.; Lioy, S.; Carisio, L.; Manino, A.; Porporato, M. Vespa velutina: An Alien Driver of Honey Bee Colony Losses. Diversity 2020, 12, 5. [CrossRef]

86. Moritz, R.F.; Haddad, N.; Bataieneh, A.; Shalmon, B.; Hefetz, A. Invasion of the dwarf honeybee Apis florea into the near East. Biol. Invasions 2010, 12, 1093-1099. [CrossRef]

87. Brittain, C.; Williams, N.; Kremen, C.; Klein, A.M. Synergistic effects of non-Apis bees and honey bees for pollination services. Proc. Royal Soc. B 2013, 280, 20122767. [CrossRef]

88. Kenis, M.; Auger-Rozenberg, M.A.; Roques, A.; Timms, L.; Péré, C.; Cock, M.J.; Settele, J.; Augustin, S.; Lopez-Vaamonde, C. Ecological effects of invasive alien insects. Biol. Invasions 2009, 11, 21-45. [CrossRef]

89. Han, P.; Niu, C.; Lei, C.-L.; Cui, J.-J.; Desneux, N. Quantification of toxins in a Cry1Ac + CpTI cotton cultivar and its potential effects on the honey bee Apis mellifera L. Ecotoxicology 2010, 19, 1452-1459. [CrossRef] [PubMed]

90. Durant, J.L.; Otto, C.R. Feeling the sting? Addressing land-use changes can mitigate bee declines. Land Use Policy 2019, 87, 104005. [CrossRef]

91. Andrews, E. To save the bees or not to save the bees: Honey bee health in the Anthropocene. Agric. Hum. Values 2019, 36, 891-902. [CrossRef]

92. Dolezal, A.G.; Toth, A.L. Feedbacks between nutrition and disease in honey bee health. Curr. Opin. Insect. Sci. 2018, 26, 114-119. [CrossRef]

93. Brodschneider, R.; Crailsheim, K. Nutrition and health in honey bees. Apidologie 2010, 41, 278-294. [CrossRef]

94. Melicher, D.; Wilson, E.S.; Bowsher, J.H.; Peterson, S.S.; Yocum, G.D.; Rinehart, J.P. Long-Distance Transportation Causes Temperature Stress in the Honey Bee, Apis mellifera (Hymenoptera: Apidae). Environ. Entomol. 2019, 48, 691-701. [CrossRef] [PubMed]

95. Strachecka, A.; Gryzińska, M.; Krauze, M. The influence of environmental pollution on the protective proteolytic barrier of the honey bee Apis mellifera mellifera. Pol. J. Environ. Stud. 2010, 19, 855-859.

96. Goulson, D.; Nicholls, E.; Botías, C.; Rotheray, E.L. Bee declines driven by combined stress from parasites, pesticides, and lack of flowers. Science 2015, 347, 1255957. [CrossRef]

97. Giannini, T.C.; Boff, S.; Cordeiro, G.D.; Cartolano, E.A.; Veiga, A.K.; Imperatriz-Fonseca, V.L.; Saraiva, A.M. Crop pollinators in Brazil: A review of reported interactions. Apidologie 2015, 46, 209-223. [CrossRef]

98. Kerr, J.T.; Pindar, A.; Galpern, P.; Packer, L.; Potts, S.G.; Roberts, S.M.; Rasmont, P.; Schweiger, O.; Colla, S.R.; Richardson, L.L.; et al. Climate change impacts on bumblebees converge across continents. Science 2015, 349, 177-180. [CrossRef]

99. Aufauvre, J.; Biron, D.G.; Vidau, C.; Fontbonne, R.; Roudel, M.; Diogon, M.; Viguès, B.; Belzunces, L.P.; Delbac, F.; Blot, N. Parasite-insecticide interactions: A case study of Nosema ceranae and fipronil synergy on honeybee. Sci. Rep. 2012, 2, 326. [CrossRef]

100. Doublet, V.; Labarussias, M.; de Miranda, J.R.; Moritz, R.F.; Paxton, R.J. Bees under stress: Sublethal doses of a neonicotinoid pesticide and pathogens interact to elevate honey bee mortality across the life cycle. Environ. Microbiol. 2015, 17, 969-983. [CrossRef]

101. Retschnig, G.; Neumann, P.; Williams, G.R. Thiacloprid-Nosema ceranae interactions in honey bees: Host survivorship but not parasite reproduction is dependent on pesticide dose. J. Invertebr. Pathol. 2014, 118, 18-19. [CrossRef]

102. Paoli, P.P.; Donley, D.; Stabler, D.; Saseendranath, A.; Nicolson, S.W.; Simpson, S.J.; Wright, G.A. Nutritional balance of essential amino acids and carbohydrates of the adult worker honeybee depends on age. Amino Acids 2014, 46, 1449-1458. [CrossRef]

103. Barber, N.A.; Soper Gorden, N.L. How do belowground organisms influence plant-pollinator interactions? J. Plant Ecol. 2015, 8, 1-11. [CrossRef]

104. Hladun, K.R.; Parker, D.R.; Tran, K.D.; Trumble, J.T. Effects of selenium accumulation on phytotoxicity, herbivory, and pollination ecology in radish (Raphanus sativus L.). Environ. Pollut. 2013, 172, 70-75. [CrossRef] [PubMed] 
105. Vanbergen, A.J.; Initiative, T.I.P. Threats to an ecosystem service: Pressures on pollinators. Front. Ecol. Environ. 2013, 11, 251-259. [CrossRef]

106. Moritz, R.F.; Erler, S. Lost colonies found in a data mine: Global honey trade but not pests or pesticides as a major cause of regional honeybee colony declines. Agric. Ecosyst. Environ. 2016, 216, 44-50. [CrossRef]

107. Hladik, M.L.; Main, A.R.; Goulson, D. Environmental Risks and Challenges Associated with Neonicotinoid Insecticides. Environ. Sci. Technol. 2018, 52, 3329-3335. [CrossRef]

108. Lushchak, V.I.; Matviishyn, T.M.; Husak, V.V.; Storey, J.M.; Storey, K.B. Pesticide toxicity: A mechanistic approach. EXCLI J. 2018, 17, 1101.

109. Simon-Delso, N.; Amaralrogers, V.; Belzunces, L.P.; Bonmatin, J.M.; Chagnon, M.; Downs, C.A.; Furlan, L.; Gibbons, D.W.; Giorio, C.; Girolami, V.; et al. Systemic insecticides (neonicotinoids and fipronil): Trends, uses, mode of action and metabolites. Environ. Sci. Pollut. Res. 2015, 22, 5-34. [CrossRef]

110. Sanchez-Bayo, F.; Goka, K. Pesticide residues and bees-a risk assessment. PLoS ONE 2014, 9, e94482. [CrossRef]

111. Tomizawa, M.; Casida, J.E. Selective toxicity of neonicotinoids attributable to specificity of insect and mammalian nicotinic receptors. Annu. Rev. Entomol. 2003, 48, 339-364. [CrossRef]

112. Van der Sluijs, J.P.; Simon-Delso, N.; Goulson, D.; Maxim, L.; Bonmatin, J.M.; Belzunces, L.P. Neonicotinoids, bee disorders and the sustainability of pollinator services. Curr. Opin. Environ. Sustain. 2013, 5, 293-305. [CrossRef]

113. Jeschke, P.; Nauen, R.; Schindler, M.; Elbert, A. Overview of the status and global strategy for neonicotinoids. J. Agric. Food Chem. 2011, 59, 2897-2908. [CrossRef] [PubMed]

114. Wilde, J.; Frączek, R.J.; Siuda, M.; Bąk, B.; Hatjina, F.; Miszczak, A. The influence of sublethal doses of imidacloprid on protein content and proteolytic activitity in honey bees (Apis mellifera L.). J. Apic. Res. 2016, 55, 212-220. [CrossRef]

115. Słowińska, M.; Nynca, J.; Wilde, J.; Bąk, B.; Siuda, M.; Ciereszko, A. Total antioxidant capacity of honey bee hemolymph in relation to age and exposure to pesticides, and comparison to antioxidant capacity of seminal plasma. Apidologie 2016, 47, 227-236. [CrossRef]

116. Ciereszko, A.; Wilde, J.; Dietrich, G.J.; Siuda, M.; Bąk, B.; Judycka, S.; Karol, H. Sperm parameters of honeybee drone exposed to imidacloprid. Apidologie 2017, 48, 211-222. [CrossRef]

117. Petanidou, T.; Kallimanis, A.S.; Sgardelis, S.P.; Mazaris, A.D.; Pantis, J.D.; Waser, N.M. Variable flowering phenology and pollinator use in a community suggest future phenological mismatch. Acta Oecologica 2014, 59, 104-111. [CrossRef]

118. Nürnberger, F.; Härtel, S.; Steffan-Dewenter, I. The influence of temperature and photoperiod on the timing of brood onset in hibernating honey bee colonies. PeerJ 2018, 6, e4801. [CrossRef]

119. Wang, Q.; Xu, X.; Zhu, X.; Chen, L.; Zhou, S.; Huang, Z.Y.; Zhou, B. Low-Temperature Stress during Capped Brood Stage Increases Pupal Mortality, Misorientation and Adult Mortality in Honey Bees. PLoS ONE 2016, 11, e0154547. [CrossRef] [PubMed]

120. VanEngelsdorp, D.; Speybroeck, N.; Evans, J.D.; Kim Nguyen, B.; Mullin, C.; Frazier, M.; Frazier, J.; Cox-Foster, D.; Chen, Y.; Tarpy, D.R.; et al. Weighing risk factors associated with bee colony collapse disorder by classification and regression tree analysis. J. Econ. Entomol. 2010, 103, 1517-1523. [CrossRef] [PubMed]

121. Memmott, J.; Craze, P.G.; Waser, N.M.; Price, M.V. Global warming and the disruption of plant-pollinator interactions. Ecol. Lett. 2007, 10, 710-717. [CrossRef]

122. Thomson, J.D. Flowering phenology, fruiting success and progressive deterioration of pollination in an early-flowering geophyte. Philos. Trans. R. Soc. Lond. B Biol. Sci. 2010, 365, 3187-3199. [CrossRef]

123. Bargańska, Ż.; Ślebioda, M.; Namieśnik, J. Honey bees and their products: Bioindicators of environmental contamination. Crit. Rev. Environ. Sci. Technol. 2016, 46, 235-248. [CrossRef]

124. Søvik, E.; Perry, C.J.; LaMora, A.; Barron, A.B.; Ben-Shahar, Y. Negative impact of manganese on honeybee foraging. Biol. Lett. 2015, 11, 20140989. [CrossRef]

125. Nikolić, T.V.; Kojić, D.; Orčić, S.; Batinić, D.; Vukašinović, E.; Blagojević, D.P.; Purać, J. The impact of sublethal concentrations of $\mathrm{Cu}, \mathrm{Pb}$ and $\mathrm{Cd}$ on honey bee redox status, superoxide dismutase and catalase in laboratory conditions. Chemosphere 2016, 164, 98-105. [CrossRef] [PubMed]

126. Lazor, P.; Tomáš, J.; Tóth, T.; Tóth, J.; Čéryová, S. Monitoring of air pollution and atmospheric deposition of heavy metals by analysis of honey. J. Microbiol. Biotechnol. Food Sci. 2020, 9, 522-533. 
127. Skorbiłowicz, E.; Skorbiłowicz, M.; Cieśluk, I. Bees as bioindicators of environmental pollution with metals in an urban area. J. Ecol. Eng. 2018, 19, 229-234. [CrossRef]

128. Goretti, E.; Pallottini, M.; Rossi, R.; La Porta, G.; Gardi, T.; Goga, B.C.; Elia, A.C.; Galletti, M.; Moroni, B.; Petroselli, C.; et al. Heavy metal bioaccumulation in honey bee matrix, an indicator to assess the contamination level in terrestrial environments. Environ. Pollut. 2020, 256, 113388. [CrossRef]

129. Schierow, L.-J.; Johnson, R.; Corn, M.L. Bee Health: The Role of Pesticides, Congressional Research Service (CRS) 2012, Reports for Congress. p. 26. Available online: https://www.fas.org/sgp/crs/misc/R42855.pdf (accessed on 28 April 2018).

130. Capri, E.; Marchis, A. Bee Health in Europe: Facts and Figures 2013. Compendium of the Latest Information on Bee Health in Europe; OPERA Research Centre, Università Cattolica del Sacro Cuore: Milan, Italy, 2013; p. 64.

131. Johnson, R.; Corn, M.L. Bee Health: The Role of Pesticides. Congressional Research Service (CRS) 2015. Reports for Congress. p. 47. Available online: http://fas.org/sgp/crs/misc/R43900.pdf (accessed on 26 June 2017).

132. Jacques, A.; Laurent, M.; EPILOBEE Consortium; Ribière-Chabert, M.; Saussac, M.; Bougeard, S.; Budge, G.E.; Hendrikx, P.; Chauzat, M.-P. A pan-European epidemiological study reveals honey bee colony survival depends on beekeeper education and disease control. PLoS ONE 2017, 12, e0172591. [CrossRef]

133. van Engelsdorp, D.; Evans, J.D.; Donovall, L.; Mullin, C.; Frazier, M.; Frazier, J.; Tarpy, D.R.; Hayes, J.; Pettis, J.S. Entombed pollen: A new condition in honey bee colonies associated with increased risk of colony mortality. J. Invertebr. Pathol. 2009, 101, 147-149. [CrossRef]

134. London-Shafir, I.; Shafir, S.; Eisikowitch, D. Amygdalin in almond nectar and pollen-facts and possible roles. Plant Syst. Evol. 2003, 238, 87-95. [CrossRef]

135. United Nations Environment Programme (UNEP). UNEP Emerging Issues: Global Honey Bee Colony Disorder and Other Threats to Insect Pollinators 2010. p. 16. Available online: http://www.unep.org/dewa/ Portals/67/pdf/Global_Bee_Colony_Disorder_and_Threats_insect_pollinators.pdf (accessed on 29 May 2016).

136. Watkins de Jong, E.; DeGrandi-Hoffman, G.; Chen, Y.; Graham, H.; Ziolkowski, N. Effects of diets containing different concentrations of pollen and pollen substitutes on physiology, Nosema burden, and virus titers in the honey bee (Apis mellifera L.). Apidologie 2019, 50, 845-858. [CrossRef]

137. DeGrandi-Hoffman, G.; Gage, S.L.; Corby-Harris, V.; Carroll, M.; Chambers, M.; Graham, H.; deJong, E.W.; Hidalgo, G.; Calle, S.; Azzouz-Olden, F.; et al. Connecting the nutrient composition of seasonal pollens with changing nutritional needs of honey bee (Apis mellifera L.) colonies. J. Insect Physiol. 2018, 109, 114-124. [CrossRef] [PubMed]

138. Hoffman, G.D.; Chen, Y. Nutrition, immunity and viral infections in honey bees. Curr. Opin. Insect. Sci. 2015, 10, 170-176. [CrossRef] [PubMed]

139. Fewell, J.H.; Winston, M.L. Colony state and regulation of pollen foraging in the honey bee, Apis mellifera L. Behav. Ecol. Sociobiol. 1992, 30, 387-393. [CrossRef]

140. Oldroyd, B.P. What's killing American honey bees? PLoS Biol. 2007, 5, e168. [CrossRef] [PubMed]

141. Groh, C.; Tautz, J.; Rössler, W. Synaptic organization in the adult honey bee brain is influenced by brood-temperature control during pupal development. Proc. Natl. Acad. Sci. USA 2004, 101, 4268-4273. [CrossRef]

142. Jones, J.C.; Helliwell, P.; Beekman, M.; Maleszka, R.; Oldroyd, B.P. The effects of rearing temperature on developmental stability and learning and memory in the honey bee, Apis mellifera. J. Comp. Physiol. A. Neuroethol. Sens. Neural. Behav. Physiol. 2005, 191, 1121-1129. [CrossRef]

143. USDA-Biotech Crop Data. Adoption of Genetically Engineered Crops in the U.S. 2009. Available online: http://www.ers.usda.gov/Data/BiotechCrops/\#2009-7-1 (accessed on 19 February 2018).

144. Johnson, R.M.; Ellis, M.D.; Mullin, C.A.; Frazier, M. Pesticides and honey bee toxicity-USA. Apidologie 2010, 41, 312-331. [CrossRef]

145. Johnson, R.M. Honey Bee Toxicology. Annu. Rev. Entomol. 2015, 60, 415-434. [CrossRef]

146. Fearing, P.L.; Brown, D.; Vlachos, D.; Meghji, M.; Privalle, L. Quantitative analysis of CryIA(b) expression in Bt maize plants, tissues, and silage and stability of expression over successive generation. Mol. Breed. 1997, 3, 169-176. [CrossRef]

147. Arpaia, S.; De Cristofaro, A.; Guerrieri, E.; Bossi, S.; Cellini, F.; Di Leo, G.M.; Germinara, G.S.; Iodice, L.; Maffei, M.E.; Petrozza, A.; et al. Foraging activity of bumblebees (Bombus terrestris L.) on Bt-expressing eggplants. Arthropod-Plant Interact. 2011, 5, 255-261. [CrossRef] 
148. Ramirez-Romero, R.; Desneux, N.; Decourtye, A.; Chaffiol, A.; Pham-Delègue, M.H. Does Cry1Ab protein affect learning performances of the honey bee Apis mellifera L. (Hymenoptera, Apidae)? Ecotoxicol. Environ. Saf. 2008, 70, 327-333. [CrossRef]

149. Paula, D.P.; Andow, D.A.; Timbo, R.V.; Sujii, E.R.; Pires, C.S.; Fontes, E.M. Uptake and transfer of a Bt toxin by a Lepidoptera to its eggs and effects on its offspring. PLoS ONE 2014, 9, e95422. [CrossRef]

150. González-Varo, J.P.; Biesmeijer, J.C.; Bommarco, R.; Potts, S.G.; Schweiger, O.; Smith, H.G.; Steffan-Dewenter, I.; Szentgyörgyi, H.; Woyciechowski, M.; Vilà, M. Combined effects of global change pressures on animal-mediated pollination. Trends Ecol. Evol. 2013, 28, 524-530. [CrossRef] [PubMed]

Publisher's Note: MDPI stays neutral with regard to jurisdictional claims in published maps and institutional affiliations.

(C) 2020 by the authors. Licensee MDPI, Basel, Switzerland. This article is an open access article distributed under the terms and conditions of the Creative Commons Attribution (CC BY) license (http://creativecommons.org/licenses/by/4.0/). 